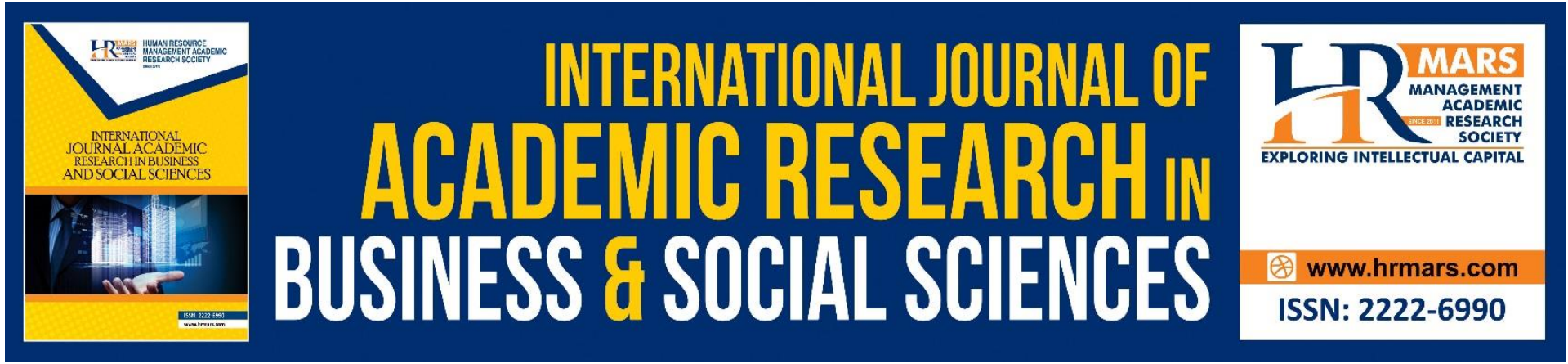

\title{
Social Media Use and Political Efficacy: Structural Effect of the Voting Decision of New Voters
}

Mohd Sufiean Hassan, Abdul Rauf Ridzuan, Abd Aziz A'zmi, Rizky Hafiz Chaniago, Siti Nurshahidah Sah Allam

To Link this Article: http://dx.doi.org/10.6007/IJARBSS/v11-i6/10205

DOI:10.6007/IJARBSS/v11-i6/10205

Received: 17 April 2021, Revised: 18 May 2021, Accepted: 09 June 2021

Published Online: 29 June 2021

In-Text Citation: (Hassan et al., 2021)

To Cite this Article: Hassan, M. S., Ridzuan, A. R., A'zmi, A. A., Chaniago, R. H., \& Allam, S. N. S. (2021). Social Media Use and Political Efficacy: Structural Effect of the Voting Decision of New Voters. International Journal of Academic Research in Business and Social Sciences, 11(6), 1827-1841.

Copyright: @ 2021 The Author(s)

Published by Human Resource Management Academic Research Society (www.hrmars.com)

This article is published under the Creative Commons Attribution (CC BY 4.0) license. Anyone may reproduce, distribute, translate and create derivative works of this article (for both commercial and non-commercial purposes), subject to full attribution to the original publication and authors. The full terms of this license may be seen at: http://creativecommons.org/licences/by/4.0/legalcode

Vol. 11, No. 6, 2021, Pg. $1827-1841$

Full Terms \& Conditions of access and use can be found at http://hrmars.com/index.php/pages/detail/publication-ethics 


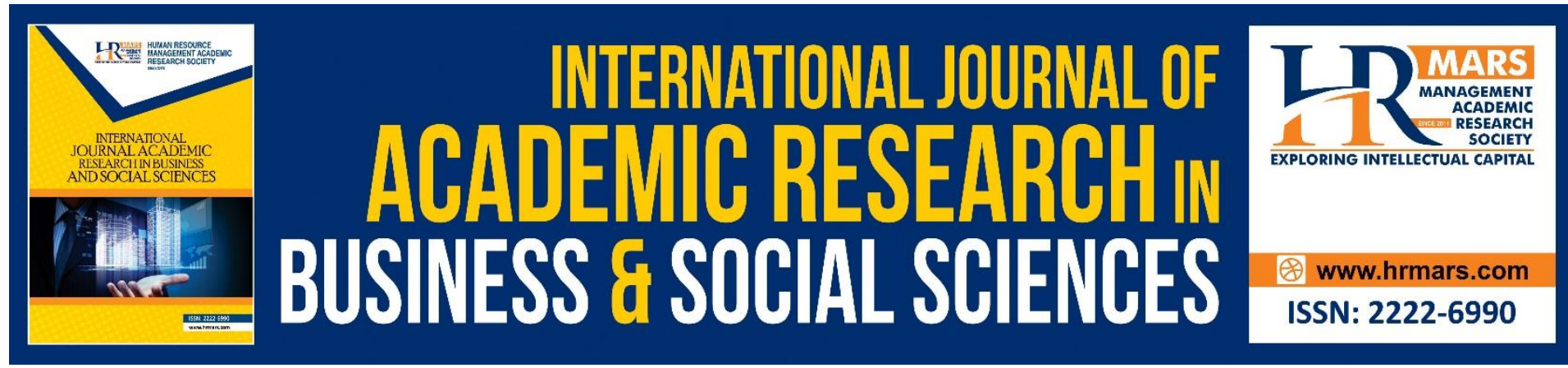

\title{
Social Media Use and Political Efficacy: Structural Effect of the Voting Decision of New Voters
}

\author{
Mohd Sufiean Hassan, Abdul Rauf Ridzuan \\ Universiti Teknologi MARA, Melaka Branch, Malaysia
}

\author{
Abd Aziz A'zmi \\ Kolej Universiti Islam Melaka, Malaysia \\ Rizky Hafiz Chaniago \\ Universiti Pendidikan Sultan Idris

\section{Siti Nurshahidah Sah Allam} \\ Universiti Teknologi MARA, Melaka Branch, Malaysia
}

\begin{abstract}
This paper explores the effect of social media use and political efficacy (internal and external efficacy) on voting decisions among new voters. The favored hypothesis states that increased social media usage and political efficacy help shape voting decisions among new voters. The decision to lowering the voting age to 18 years by the parliament has cast doubt on political efficacy that leading to voting decisions among new voters. Social Media has proven to be a catalyst for social change in Malaysia since the 2004 election. Since the importance of social media use and political efficacy as a source of a healthy democracy, this study examines the effect of social media usage and political efficacy dimensions such as internal political efficacy and external political efficacy to voting decisions among new voters. A survey was used for data gathering among 384 school students and Higher Education Institution students in Melaka. The data analyzed descriptively and inferentially using SPSS and SEM AMOS to provide an empirical understanding of social media use and political efficacy contribution towards the decision to vote. This study presents the significant effect of social media use and political efficacy from internal and external political efficacy to voting decisions among new voters. Surprisingly, educated young people claimed from the previous study have little interest in politically engaging in social media.
\end{abstract}

Keywords: Social Media Use, Internal Efficacy, External Efficacy, New Voter, Decision to Vote

\section{Introduction}

Exposure to political, social media web most often employed a higher level of political engagement (Neil, 2010), and a survey among young Belgian found that increasing time spent 
being online can lead to a growth in political interest and political participation among young people (Ellen \& Sara, 2008). Come to terms political participation as being registered voters and turn out during the election, many scholars found a positive relationship between the use of the Internet and social media for political purposes and general political participation (Vitak, 2010; Adnan et al., 2012; Hsu \& Park, 2012). According to Gerber, Alan, Dean \& Daniel (2007), who conducted a cross-sectional survey on 15 countries to examine expressive engagement, political knowledge, and young voter turnout reported newspaper readership found a positive relationship between political knowledge and political participation. Besides, (Najin, 2012) who surveyed Internet news exposure among young voters, urged that Internet exposure has no direct relationship with political participation. However, the impact on social media, political efficacy and political participation among young people have a different point of view where young people are not interested in reading a newspaper and searching political news from the conventional media (Rebecca, 2009).

A study conducted in social network and political content found that social networks do not drive active political participation among young people even though there are exposed to political content, but a request for political participation remains passive (Gustafsson, 2012) However, a survey among England young voters that there is a weak relationship between Internet news and political participation but a positive relationship with political knowledge. Also, a survey conducted on political Facebook and political knowledge slightly correlate with many media scholars where participation with the online political group is strongly correlated with offline political participation. Many scholars report that daily newspapers have a greater impact and positive relationship with political participation among young people.

The role of conventional media and the Internet concerning young people's political participation has attracted a great deal of scholarly attention. As a result, from meta-analysis, media scholars focused on the findings for Internet news and political participation. But, little attention on the correlation between social media, political efficacy, and political participation (voting decision). Various findings found a correlation between social media and political participation. Negative relationships reported by scholars may cause different justification on political participation, and they strictly focus on online political news as political information or political updates. However, it is failed to confirm a relationship between political efficacy and online political participation (Conroy \& Feezel, 2012).

In addition, the Internet is the best medium to examine young people's trends on searching political information because they are identified as technology-savvy way before the old citizens. Social media features are more user-friendly to share their political beliefs and ideology, support selected political candidates, political self-expression, and interact with others who share similar interests on political issues. Supported by Tien-Tsung \& Lu Wei 2008, newspaper use is generally connected to greater political trust and political knowledge where newspaper features to inform and educate citizens because it provides more thematic and historical context, emphasizing more complex issues and policies than newspapers simplistic strategic is undeniable. Political campaigns on social media, especially during general elections urged more effective than conventional media such as newspapers.

As a result, from meta-analysis, media scholars focused on the findings for Internet news and political participation. But, little attention on the correlation between social media, political efficacy, and the decision to vote. This study is conducted to examine the effect between social media use, political efficacy, and the decision to vote among new voters. In the past 12th General Election (GE 12), Malaysia faced difficulty in encouraging new and young voters to turn out, but the issue of the 3.6 million people who have not registered as 
voters is no longer a critical topic to be highlighted. From the latest record by the Election Commission (EC) obtained by BCC News (Lin, 2018), there are 6.1 million young voters between the age of 21 to 30 . From statistics, $41 \%$ of the eligible voters are between the ages of 21 and 30. This group is categorized as emotionally influenced, willing to go to the streets to make their voice heard, like in the Bersih 3.0 rally and the protest on PTPTN. The young voters will be the determining force in the 15th general election (15th GE). However, factors influencing new voters to vote are complex and cannot be determined using a single factor or a simple reason (Bhothisawang, 2018), and it varies among individuals. This section emphasizes social media use, internal political efficacy, and external political efficacy.

At one time, political participation among young people was reported lower than adult and justification of lower turnout rate due to complicated and bureaucracy in political participation (Ali et al., 2011). Nowadays, rapid technology change affected the advancement of communication; social media (Guo, 2014). Innovation of social media alleged by scholars as key factors embark high political inclination that influences young people political interest (Holt et al., 2013). Undeniable, political participation among young people causes dramatic changes in the political arena (Al-Kandari \& Hasanen, 2012).

The first wave sparks during General Election (GE) 12, and some believe that this is 'Tsunami Politik Melayu' (Salleh, 2008) and 'Tsunami Politik Anak Muda Cina' (Pong, 2012). The explosion of political interest among young people continues to GE 13 (Kasmani et al., 2014), proven that participation by young people in the democracy process causes dramatic changes in Malaysia's political sphere. Tracking the involvement of young people in political activities can change Malaysia political sphere; idea spark by politician proposes to lowering the voting age to 18 , and critics of giving citizens under 21 to vote to argue that such teenagers lack political interest (Zhang \& Chia, 2006) and little motivation to search political knowledge that drives them to participate effectively in elections (Anduiza et al., 2012).

Technology rapidly changes the political sphere in Malaysia, including determinants of the minimum voting age. Technology especially social media offers various political participation and provide multiple platforms of political activities among citizens. The innovation of cyber communication, especially social media, offers an interactive platform to young people aged 18 (known as new voters of 18 ) to engage in political activities.

Aggressive political engagement in social media leads to low integrity participation, such as joining street demonstrations and provocation that purposely create damage on political party. This scenario directly affects national cybersecurity while young people engagement predisposed to cybercrime such as cyberstalking and creating deep fake.

Policymakers believe that awarding political rights and responsibility to new voters of 18 can mold their engagement in line with integrity conduct. As a result, lowering the voting age seems relevant in the current situation in Malaysia. Propose by the politician to lowering the voting age from 21 to 18, a key question in an ongoing discussion about voting age is whether people in 18 are politically mature enough to take part in political activities since adult voters predict them since they lack political inclination that causes little motivation in searching political knowledge and fragile decision on political preferences.

However, these are the stigmatization of a group of people who oppose lowering the voting age. They believe that our teenagers of 18 are not politically well informed, no political interest. If voting rights are given to them, it would have negative consequences for the quality democracy. Why lowering the voting age? A group of people who seek the core quality of democratic citizenship and participation in the national agenda prone to support the idea of lowering the voting age to 18 . Awarding voting rights to 18 years old is important given the 
changing age demographic in the country, which resulted in participation from various generations in the political arena, which contributes to the idea for Malaysia's development.

In addition, consistent rules and regulations impose on 18 prove that they are responsible and mature enough. The age of 18 teenagers is responsible under the legal age of Malaysia that imposes to them Criminal Act, Labour Act, Taxation Act, marriage age, smoking age, they are eligible to join arm forces and part of political association members. Awarding voting rights to 18 years old is important given the changing age demographic in the country, which resulted in participation from various generations in the political sphere, which contributes to the idea for Malaysia's development.

This research is important to be carried out as it is in line with the government's initiative to promote youth empowerment initiative that stated in National Mission 2020 and mentioned by the Ministry of Youth and Sports Malaysia in strategic thrust, empowering young people will be allowed to determine the direction and planning of the organization. Youth leadership is nurtured in producing global youth and nurturing communities. After 60 years, empowering teenagers of 18 can enhance their responsibility towards the country. Malaysia will be known as one of the states who practice healthy democracy by giving rights to them involving political activities.

The decision to lower the voting age must have an empirical explanation, and even though this notion is discussed, there is no systematic model developed from the previous study. By having this model, the foundation lowering voting age by government and policymaker being justified. In addition, this model can measure the level of internal political efficacy and external political efficacy among new voters as an indicator of their level of political participation readiness.

\section{Social Media Use}

Young people regard the Internet as a flexible medium for information seeking (KyungSun Kim 2013) (Dana Rosengard 2014), get political news update (Ingrid Bachmann 2013), online political messaging for opinion expression (Valenzuela 2013), and political expression (Masahiro Yamamoto 2014) enhance through a mobile political application.

According to Sufiean et al. (2016), social media help to increase new voter intention to participate in the general election. However, Pinkleton (2012) stresses that greater exposure to negative political issues or dissatisfaction with media can affect participants' cynicism, and political apathy will lead to lower political participation among young people. It also will affect the different levels of political participation, either participate or not to participate.

Biswas et al (2014) findings show that social media significantly influences people's voting behavior in large and semi-urban areas through social media. Social media plays a vital role in the voting behavior of young voters through the use of attractive advertisements, especially towards students. It is not only can attract people's attention even shaping the behavior to turning out during the election. Their study also found that people who actively use social media tend to decide based on the political content he reads. Social media raises awareness among the public and serves as a force to demand individual's turnout and vote. YouTube is among the sources of information that decide to vote (Biswas et al., 2014).

According to Bashky et al (2012), social media dramatically influences voter participation in elections. Facebook is found to be a digital platform that has high political sentiment among users. This is due to its function that allows users to comment and share status, audio, and visuals with other users. In addition, they also can interact and participate 
in the existing public debate space. Besides, Junaidi (2010) stated that social media such as Facebook and Twitter is massive in political behavior among students. One of the understandable political behaviors is the decision to vote during an election. In the 14th general election (GE), the prominence of people's issues such as rising prices of goods and petrol, corruption, nepotism, implementation of GST, and marketability of graduates impacted voting behavior in the election (Hamedan et al., 2019).

Chen (2016) stated that today's social media networks could lead to an increase in political participation, among which is voting in elections. In another study, the level of political participation through social media or influenced by social media was high among young people, especially students (Zainon \& Hashim, 2017). In the United States, the impact of social media on turnout also shows a direct correlation. Social media is found to have a substantial impact on citizens who are already interested in politics, so they are more oriented to go out and vote (Steinberg, 2015). Thereby, we propose the following:

\section{H1: Social media use significantly influence decision to vote among new voters}

\section{Internal Political Efficacy}

In particular, internal political efficacy may have less explanatory value in predicting unexpected or habitual behaviour, simply due to the more influential role of other motivational forces and automatic activation (Bargh, 1997). Indeed, evidence suggests that intentional behaviour can be explained through internal efficacy, also represented as perceived behavioural control (Fishbein \& Ajzen, 1981). It is referred to as internal political efficacy in the political realm and should be necessary to engage in cognitively sophisticated political activities that require planning and devotion to politics. Recent research suggests that the effect of this variable might be constrained to certain types of behaviour and/or populations (Cicognani et al., 2016; Reichert, 2016).

Studies on political efficacy in Germany stated that internal political efficacy is translated from political knowledge and then influences various actions of political participation, including conventionally, i.e., going out to vote (Reichert, 2016). Internal efficacy is also described by Ajzen (2012) as something that increases the willingness to participate. Such willing behavior is an essential primary condition in determining actual action or behavior. This is also in line with Deth, Montero, \& Westholm (2007) statements, particularly in the context of voting turnout.

Studies in 24 European and American countries (1999-2000) on political efficacy explain the findings of the study based on individuals and countries in general. Individually, internal efficacy plays a significant role in driving a person's likelihood of engaging with political participation. In general, at the national level, internal efficacy drives the probability of participation in representative forums. However, it does not directly lead to turnout results. Thus, individual representative participation is determined by internal efficacy, whereas voting exit is seen as a conventional civic norm (Amna, Munck, \& Zetterberg, 2004).

Schulz (2005) states that voting is one of the political participation, which is also referred to as electoral participation. This action is the least intensive political participation compared to other political activities. According to him, electoral participation is related to political interests, knowledge, trust, and political communication. The study's findings state that internal efficacy is related to political interests, political discussion, and media use. Thus, internal efficacy indirectly contributes to the voting activity, which is electoral participation. Reichert (2016), who conducted a study on respondents who lived in Germany aged 16 years 
and older, also found that internal political efficacy did not directly affect the decision to vote, but it had an indirect influence through the conscious decision actually to vote.

Political internal efficacy is also referred to as political self-efficacy that justifies political engagement, when a person frequently obtains information related to political issues, impacting voting behavior. The more a person engages in political engagement, the higher self-efficacy one's has (Tuinhof, 2016). The term self-efficacy was also used in the study by Children of the National Longitudinal Study of Youth. The study's findings explain that selfefficacy has a positive effect on voting behavior among young people who are first-time voters. This relationship also contributes to the turnout in elections, especially from lowincome families (Condonm \& Holleque, 2013).

Moreover, a person with a high level of internal efficacy is said to have low external efficacy, tending to participate conventionally. Conventional is meant, as stated by Verba \& Nie (1972), as "within-system" behavior that is voting (Philip, 1983). Hence, we posit that:

\section{H2: Internal Political Efficacy significantly influence decision to vote among new voters}

\section{External Political Efficacy}

Studies on external efficacy were conducted in New Zealand on non -voters and young non voters. External efficacy is more on the behavior of young people who do not vote. Young people who do not vote in different places have low external efficacy. These groups are not interested in turning out to vote because they are not interested in politics, politics is irrelevant, complex, politicians cannot be trusted and voting does not change anything (Sheerin, 2007). Other studies have also shown the existence of relationships that show low external efficacy or the opposite with high internal efficacy show a negative effect on voting turnout actions (Ha et al., 2012).

External efficacy is also associated with studying the relationship between the maturity of the age of democracy in a place and the turnout. The findings of the study explain, the longer the age of democratic maturity in a place, the higher the level of external effectiveness and participation in elections (Novy \& Katrnak, 2015). In general, the level of external efficacy varies based on the age of maturity of an old or new democracy in a place. The findings of this study are in line with studies conducted among students in democratic and post-communist European countries. Levels of external efficacy and expectations for active participation when they are adults were found to be low in Slovenia and Poland. These two countries are post-communist countries whose democratic maturity age is younger than other European countries (Schulz, 2005). Thus, it is hypothesized that:

\section{H3: External Political Efficacy significantly influence decision to vote among new voters}

Based on the above said reviews of literature, a theoretical framework is proposed (see Figure 1).

\section{Methodology}

Data were collected from pre-screened school and university students studying in Melaka, Malaysia, who age 16 to 21 and have experience using social media to get political information, a method of quantitative research employing convenience sampling techniques, from 1 to 30 September 2019. Initially, 300 questionnaires were administered; however, a total of 384 unique and usable responses were successfully collected for a response rate of 80 percent. The structured close-ended questionnaire was designed in line with this study's 
research objective of examining structural relationships of social media use, internal political efficacy, and external political efficacy with the decision to vote among young voters-the questionnaire comprised four sections. Section A consisted of respondents' demographic profile. Section $B$ requested the respondents to respond to their personal experiences using social media to get information about politics, and Section $\mathrm{C}$ examined the political efficacy among new voters. Section $D$ examined the decision to vote among new voters. In total, 17 items (described in Appendix A), were used to measure the four independent variables: Social media use, internal political efficacy, and external political efficacy, and 12 questions were used to measure the dependent variable: the decision to vote on a five-point Likert scale ranging from 1 strongly disagree to 5 strongly agree. Survey instruments were adapted from the following sources: social media use (Zhang \& Lin, 2014), internal political efficacy and external political efficacy (Sarieva, 2018), and decision to vote (Muhammad \& Hasan, 2016). Completed questionnaires were keyed in the computer program Statistical Package for Social Sciences version 20.0 to process and analyse the data in the form of descriptive such as frequencies, mean, standard deviation, skew, and kurtosis. Next, a graphical model development known as path diagram was drawn using the structural equation modelling (SEM) technique via AMOS 20.0 computer program, which has the ability to ensure the consistency of the model with the data and to estimate effects among constructs.

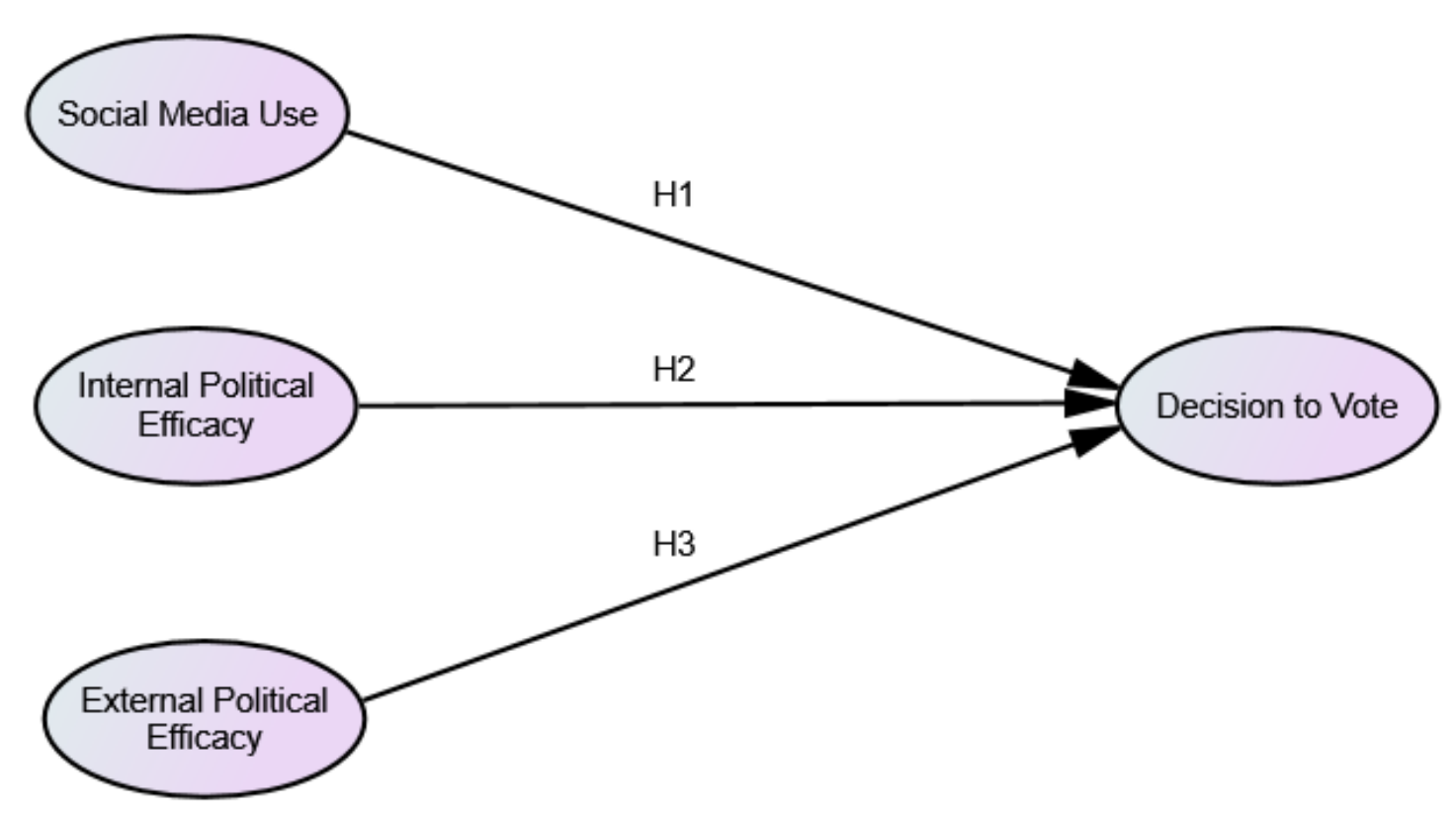

Figure 1 : Theoretical framework

\section{Data Analysis}

Table 1 displays the demographic profile of the respondents. A total of 384 participants were included in the final sample, out of which the majority of the respondents were female $(70.3$ percent), the remainder (29.7 per cent) were male. 6.3 percent of the students, or 24 of them, are between 16-17, 53.1 percent of the students, or 204 of them, are between the age of 1819 , and the remaining 40.6 percent of the student are aged between $20-21$ years. The majority of the respondents have been educated to college or higher education level: 1.0 are PMR, $35.9 \%$ are SPM and $63 \%$ diploma holders. More than $98 \%$ respondents are Malay. In addition, 63.5 of the respondents were among B40 in terms of family income. 
Table 1 : Demographic profile of respondents $(n=384)$

\begin{tabular}{lll}
\hline Variable & Frequency & Percentage \\
\hline Age & & \\
$16-17$ & 24 & 6.3 \\
$18-19$ & 204 & 53.1 \\
$20-21$ & 156 & 40.6 \\
$\begin{array}{l}\text { Gender } \\
\text { Male }\end{array}$ & 114 & 29.7 \\
Female & 270 & 70.3 \\
Level of Education & & \\
PMR & 4 & 1.0 \\
SPM & 138 & 35.9 \\
Diploma & 242 & 63.0 \\
Race & & \\
Malay & 378 & 98.4 \\
Chinese & 2 & 0.5 \\
Indian & 4 & 1.0 \\
Others & - & - \\
Family Income & & \\
B40 (Below RM 3,000) & 244 & 63.5 \\
M40 (Below RM 6,000) & 114 & 29.7 \\
T20 (RM 13,000 and & 26 & 6.8 \\
above) & & \\
\hline
\end{tabular}

\section{Convergent Validity}

The standardized loading items shown in Table 2 were considered significant as they surpassed the cut-off value of 0.50 (Hair et al., 2010). The average variances extracted (AVE) of latent constructs, range from 0.500 to 0.616 and exceed the recommended threshold value of 0.50 (Hair et al., 2014), which meant that more than one-half of the variances observed in the items were accounted for by their hypothesized constructs. Hence, the current data have good convergent validity.

\section{Discriminant Validity}

Discriminant validity was checked by comparing the shared variances between factors with the square root of AVE for each construct. Table 2 shows that all shared variances of one construct with other constructs were lower than the square root of AVE of the individual factors, confirming adequate discriminant validity. Hence, each construct was statistically different from the others. The results described in Table 3 reveal that there is a significant negative correlation between social media use variables at the 0.05 level and has the strongest correlation with decision to vote $(r=-0.469, p<0.05)$, followed by internal political efficacy $(r=0.297, p<0.05)$ and external political efficacy $(r=0.220, p<0.05)$. 
Table 2 : Reliability and validity analysis

\begin{tabular}{|c|c|c|c|c|c|c|}
\hline \multicolumn{2}{|c|}{ Constructs } & \multirow{2}{*}{$\begin{array}{l}\text { Items } \\
\text { SM1 }\end{array}$} & \multirow{2}{*}{$\begin{array}{l}\text { Standardized } \\
\text { loadings }\end{array}$} & \multirow{2}{*}{$\begin{array}{l}\text { Cronbach's } \\
\alpha \\
0.827\end{array}$} & \multirow{2}{*}{$\begin{array}{l}\text { Composite } \\
\text { reliability }\end{array}$} & \multirow{2}{*}{$\begin{array}{l}\text { Average } \\
\text { variance } \\
\text { extracted } \\
0.555\end{array}$} \\
\hline Social & Media & & & & & \\
\hline \multirow{3}{*}{\multicolumn{2}{|c|}{ Use }} & SM2 & 0.845 & & & \\
\hline & & SM3 & 0.697 & & & \\
\hline & & SM4 & 0.674 & & & \\
\hline Internal & & IPE1 & 0.622 & 0.836 & 0.832 & 0.500 \\
\hline Political & & IPE2 & 0.681 & & & \\
\hline \multirow{3}{*}{\multicolumn{2}{|c|}{ Efficacy }} & IPE3 & 0.713 & & & \\
\hline & & IPE4 & 0.753 & & & \\
\hline & & IPE5 & 0.755 & & & \\
\hline External & & EPE1 & 0.655 & 0.811 & 0.826 & 0.616 \\
\hline Political & & EPE2 & 0.902 & & & \\
\hline Efficacy & & EPE3 & 0.779 & & & \\
\hline Decision & to & DTV1 & 0.711 & 0.934 & 0.929 & 0.526 \\
\hline \multirow[t]{11}{*}{ vote } & & DTV2 & 0.795 & & & \\
\hline & & DTV3 & 0.891 & & & \\
\hline & & DTV4 & 0.804 & & & \\
\hline & & DTV5 & 0.810 & & & \\
\hline & & DTV6 & 0.603 & & & \\
\hline & & DTV7 & 0.541 & & & \\
\hline & & DTV8 & 0.646 & & & \\
\hline & & DTV9 & 0.762 & & & \\
\hline & & DTV10 & 0.672 & & & \\
\hline & & DTV11 & 0.741 & & & \\
\hline & & DTV12 & 0.647 & & & \\
\hline
\end{tabular}

Table 3 : Inter-construct correlations

\begin{tabular}{lllll}
\hline & 1 & 2 & 3 & 4 \\
\hline 1 Social media use & $\mathbf{0 . 7 4 5}$ & & & \\
2 Internal Political Efficacy & 0.528 & $\mathbf{0 . 7 0 7}$ & & \\
3 External Political Efficacy & $* * 0.118$ & $* * 0.677$ & $\mathbf{0 . 7 8 5}$ & \\
4 Decision to Vote & $* *-0.215$ & $* * 0.203$ & $* * 0.351$ & $\mathbf{0 . 7 2 5}$ \\
Mean & 1.93 & 2.66 & 2.92 & 3.61 \\
Standard Deviation & 0.898 & 0.896 & 1.023 & 1.077 \\
Skewness & 1.358 & 0.723 & 0.629 & -0.530 \\
Kurtosis & 2.190 & 0.711 & -0.023 & -0.627 \\
\hline
\end{tabular}

Notes: ${ }^{* *}$ Correlation is significant at the 0.01 level (two-tailed). Diagonal elements show the average variance extracted; off-diagonal elements show the shared variance

\section{Structural Model}

The structural model in the SEM was evaluated by examining fit indices and variance explained estimates. A variety of indices were used to assess the model's overall $t$ (see Table 4). The results indicated that the $x 2$ of the model was 759.629 with 238 of freedom ( $x 2 / d f=$ 3.192 ) and root mean square error of approximation (RMSEA) of 0.076 . The indices value for 
comparative fit index (CFI), and incremental of fit index (IFI), were above 0.90 and RMSEA below 0.08 (Kline, 2010; Bentler, 1990; Byrne, 2001), indicating a satisfactory fit. Therefore, the hypothesized model was a good fit and acceptable. The results in Figure 2 exhibit that all independent variables accounted for 21 percent of the total variance in the decision to vote $(R 2=0.21)$. As a consequence, the results are a sign of adequate model fit between the proposed research model and the empirical data. Table 5 and Figure 2 disclose the standardized path coefficients of the structural model under investigation which indicate the strength of the direct relationship between constructs. The strongest significant determinant of the decision to vote among new voters users was social media use $(\beta 1=-0.469, p<0.05)$, supporting $\mathrm{H} 1$. Next, Internal political efficacy $(\beta 2=0.297, p<0.05)$ as posited in $\mathrm{H} 2$ also significantly influenced the decision to vote among new voters. As expected, the $d$ decision to vote among new voters is also affected by external political efficacy $(\beta 3=0.220, p>0.05)$, thus $\mathrm{H} 3$ sustained.

Table 4: Confirmatory Factor Analysis (CFA)

\begin{tabular}{lllllllll}
\hline Description & $\chi \mathbf{2}$ & CMINDF & RMSEA & GFI & IFI & TLI & CFI & PGFI \\
\hline Model CFA & 759.629 & 3.192 & .076 & 0.862 & 0.903 & 0.887 & 0.903 & 0.684 \\
\hline
\end{tabular}

\section{Discussion}

The structural relationship of social media use, internal efficacy, and external efficacy with the decision to vote was investigated using empirical analysis across a sample of 320 respondents using the SEM approach. Results divulged that social media use affected the negative decision to vote among new voters at 0.05 level $(\beta 1=-0.469)$, as presented in Table 5 and Figure 2, thus supporting $\mathrm{H} 1$. This is confirmed as the most influential factor. The findings are consistent with the previous study by Pinkleton (2012). He stresses that greater exposure to negative political issues or dissatisfaction with media can affect participants' cynicism and political apathy will lead to lower political participation among young people. As expected, internal efficacy was found to have a positive significant effect on the decision to vote among new voters at 0.05 level $(\beta 2=0.297)$, as presented in Table 5 and Figure 2 , thus supporting $\mathrm{H} 2$. This portends that young people who are knowledgeable and understandable about politics are more likely to have a positive attitude towards the decision to vote. The findings are consistent with the preceding discovery by Ajzen (2012). Political knowledge and influences from various actions of political participation can increase the willingness to participate. External political efficacy has a significant positive effect on the decision to vote predictors at 0.05 level $(\beta 3=0.220)$, as presented in Table 5 and Figure 2, thus supporting H3. As expected new voters with a higher level of external political efficacy will actively participate in elections. 


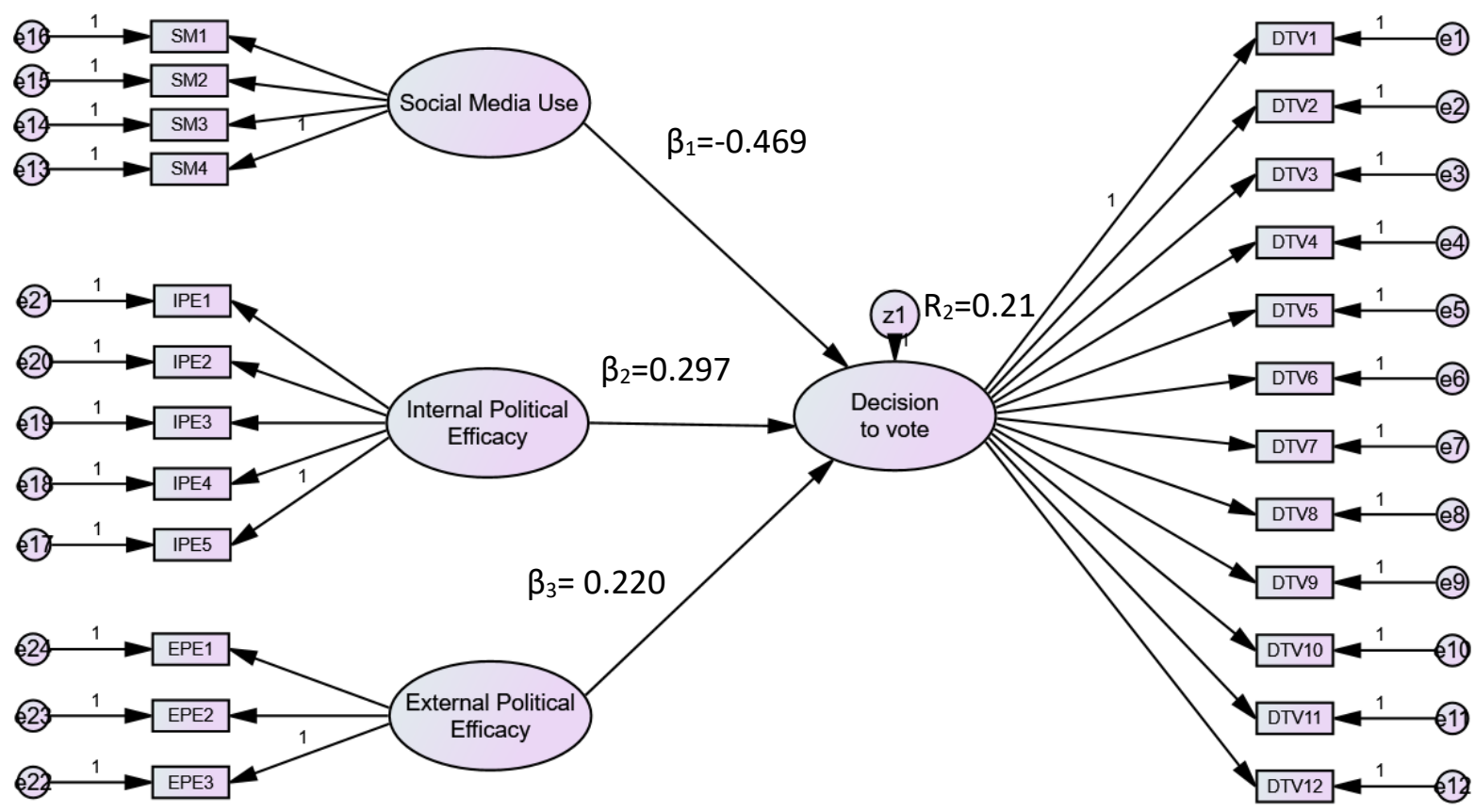

Figure 2: The results of structural model

Table 5: Relationship with decision to vote

\begin{tabular}{|c|c|c|c|c|c|c|c|c|c|}
\hline & Path & & & & & Estimate & SE & CR & $p$ \\
\hline $\mathrm{H} 1$ & \multicolumn{2}{|c|}{ Social media use } & $\rightarrow$ & $\begin{array}{l}\text { Decision } \\
\text { vote }\end{array}$ & to & -.469 & .103 & -4.563 & $* * *$ \\
\hline $\mathrm{H} 2$ & $\begin{array}{l}\text { Internal } \\
\text { Efficacy }\end{array}$ & Political & $\rightarrow$ & $\begin{array}{l}\text { Decision } \\
\text { vote }\end{array}$ & to & .297 & .142 & 2.094 & .036 \\
\hline H3 & $\begin{array}{l}\text { External } \\
\text { Efficacy }\end{array}$ & Political & $\rightarrow$ & $\begin{array}{l}\text { Decision } \\
\text { vote }\end{array}$ & to & .220 & .089 & 2.461 & .014 \\
\hline
\end{tabular}

Note: ${ }^{*} p<0.05$

\section{Conclusion and Recommendations}

In Malaysia, the lowering of the voting age was approved by Cabinet and the decision made to reduce voting age from 21 to 18 due to enhance the government's initiative to promote youth empowerment program. To make the initiative becoming practice the new young voters are automatically registered as an eligible voter. Drastic decision predicted may spark the issue of decision to vote. This study was conducted to analyse the impact of social media use, internal political efficacy and external political efficacy toward the decision to vote among new young voters (age 16 to 21). Surprisingly, our new young voters who claim has little or no interest in political activities favour for voting decision. This study found that social media use has a significantly influence voting decision among new young voters. This study provides an empirical insight for understanding phenomenon of voting decision among new young voters that influence by social media use, internal political efficacy and external political efficacy. This study confirmed that, the government's decision for lowering voting age is worth to increase political participation among young people. By the age of 16 to 21 years old, they have political inclination and possess a tendency to perform their votes during 
elections. Contribution of this study towards the expansion of political communication knowledge by enhancing thorough understanding of the determinants of the decision to vote among new voters by emphasizing the dimensions of social media use, internal political efficacy, and external political efficacy.

\section{Acknowledgement}

This work was supported by Internal TEJA Grant 2021, UiTM Melaka Branch, Malaysia (GDT2021/1-1).

\section{References}

Ajzen, I. (2012). Martin Fishbein's legacy: The reasoned action approach. The Annals of the American Academy of Political, 11-27.

Ali, S., Safar, M. H., Salman, A., Hasim, M. S., Baru, M., \& Landskap, P. (2011). New media and democracy: The changing political landscape in Malaysia. Akademika, 81(1), 15-21.

Al-Kandari, A., \& Hasanen, M. (2012). The impact of the Internet on political attitudes in Kuwait and Egypt. Telematics and Informatics, 29(3), 245-253. https://doi.org/10.1016/j.tele.2011.10.005

Amna, E., Munck, I., \& Zetterberg, P. (2004). Meaningful Participation? Political Efficacy of Adolescent in 24 Countries. Sweden.

Anduiza, E., Gallego, A., \& Jorba, L. (2012). Internet Use and the Political Knowledge Gap in Spain. Revista Internacional de Sociología, 70, 129-151. https://doi.org/10.3989/ris.2010.01.18

Bashky, E., Rosenn, I., \& Marlow, C. \&. (2012). The role of social networks in information diffusion. Proceedings of the 21st International Conference on World Wide Web, (pp. 519-528).

Bhothisawang, P. (2018). Factors influencing voters to local administration election in Pattalung Province, Thailand. SSRN Electronic Journal, 2(1), 57-72. https://doi.org/10.2139/ssrn.3229225

Biswas, A., Ingle, N., \& Roy, M. (2014). Influence of social media on voting behaviour. Journal of Power, Politics and Governance, 127-155.

Chen, J. (2016). Can online social networks foster young adults' civic engagement?. Telematics and Informatics, 487-497.

Cicognani, E., Albanesi, C., Mazzoni, D., Prati, G., \& Zani, B. (2016). Explaining offline and online civic engagement intentions between Italian and migrant youth. Revista de Psicologia Social, 31(2), 282-316. https://doi.org/10.1080/02134748.2016.1143177

Condonm, M., \& Holleque, M. (2013). Entering politics: General self effication and voting behaviour among young people. Political Psychology, 112-125.

Deth, J. v., Montero, J. R., \& Westholm, A. (2007). Citizenship and involvement in European democracies: A comparative. London: Routledge.

Ha, L., Wang, F., Fang, L., Yang, C., Hu, X., Yang, L., \& Xu, Y. (2012). Political efficacy and the use of local and national news media among undecided voters in a swing state: A study of general population voters and first-time college student voters. School of Media and Political Communication, 1-29.

Hair, J. F., Black, W. C., Babin, B. J., \& Anderson, R. E. (2014). Multivariate Data Analysis. Pearson Education Limited.

Hamedan, N. N., Alsagoff, S. A., \& Ghazali, A. H. (2019). Media, isu dan tingkah laku pengundi dalam pilihan raya umum ke-14: satu kajian awal. Journal of Communication, 293-312. 
Holt, K., Shehata, A., Strömbäck, J., \& Ljungberg, E. (2013). Age and the effects of news media attention and social media use on political interest and participation: Do social media function as leveller? European Journal of Communication, 28(1), 19-34. https://doi.org/10.1177/0267323112465369

Junaidi, A. (2010). Trend pengundian etnik melayu dan cina/tioghoa dalam pilihan raya 20092011 di malaysia. Bangi : Institut Kajian Etnik (KITA) UKM.

Kasmani, M. F., Sabran, R., \& Ramle, N. A. (2014). Who is tweeting on \#PRU13? Asian Social Science, 10(18), 144-157. https://doi.org/10.5539/ass.v10n18p144

Lin, M. M. (2018). Malaysia's youth have power they won't use. BBC News, Kuala Lumpur.

Hassan, M. S., Sah Allam, S. N., Mohd Azni, Z., \& Khamis, H. (2016). Social media and political participation among young people. Jurnal Sains Sosial, 1(1), 95-114.

Muhammad, H. J., \& Hasan, S. S. (2016). Development of the decision to vote scale. Pakistan Journal of Social and Clinical Psychology, 14(2), 10-14.

Novy, M., \& Katrnak, T. (2015). Democratic Maturity, External Efficacy and Participation in Election: Towards macro-micro Interaction. Austrian Journal of Political Science, 1-20.

Philip H, P. I. (1983). The participatory consequences of internal and external political efficacy: A research note. The Western Political Quarterly, 400-409.

Pong, T. ker. (2012). Aktivisme mahasiswa cina era reformasi dan pasca reformasi di Malaysia: Kajian impak politik dalam pilihan raya umum ke-12. Akademika Journal, 82(1), 91-102.

Reichert, F. (2016). How internal political efficacy translates political knowledge into political participation: Evidence from Germany. Europe's Journal of Psychology, 12(2), 221-241. https://doi.org/10.5964/ejop.v12i2.1095

Salleh, N. M. (2008). Pilihan Raya Umum Ke-12 (Pru-12): "Tsunami" politik melayu ? Jebat: Malaysian Journal of History, Politics \& Strategic Studies, 35(April), 49-64.

Sarieva, I. (2018). How to Measure Perceived Political Efficacy? A Three-Component Scale. Psychology, Journal of the Higher School of Economics, 15(3), 477-490. https://doi.org/10.17323/1813-8918-2018-3-477-490

Schulz, W. (2005). Political efficacy and expected political participation among lower and upper. Melbourne: Australian Council for Educational Research.

Steinberg, A. (2015). Exploring web 2.0 political engagement: Is new technology reducing the biases of political participation?. Electoral Studies, 102=116.

Zainon, N., \& Hashim, R. (2017). Political voice of young Malaysians: Online political participation among university students. International Journal of Academic Research in Business and Social Sciences, 649-654.

Zhang, W., \& Chia, S. C. (2006). The effects of mass media use and social capital on civic and political participation. Communication Studies, 57(3), 277-297. https://doi.org/10.1080/10510970600666974

Zhang, X., \& Lin, W.-Y. Y. (2014). Political participation in an unlikely place: How individuals engage in politics through social networking sites in China. International Journal of Communication, 8(1), 22. http://ijoc.org/index.php/ijoc/article/view/2003 
Appendix 1: Construct and Measurement Item of Social Media Use, Internal Political Efficacy and External Political Efficacy

\section{Social Media Use}

I read hard news via social media.

$\begin{array}{lllll}1 & 2 & 3 & 4 & 5\end{array}$

I repost photos or videos clips on government or politics.

$\begin{array}{lllll}1 & 2 & 3 & 4 & 5\end{array}$

I upload photos or videos shot by yourself on non-recreational latest

$\begin{array}{lllll}1 & 2 & 3 & 4 & 5\end{array}$

events.

I vote online.

$\begin{array}{lllll}1 & 2 & 3 & 4 & 5\end{array}$

I write blogs on government or politics, such as politics, economics, or $\begin{array}{llllll}1 & 2 & 3 & 4 & 5\end{array}$ international relations.

I join topic discussions of politics via social media.

$\begin{array}{lllll}1 & 2 & 3 & 4 & 5\end{array}$

I post political issues on social media and seek help or discussion.

$\begin{array}{lllll}1 & 2 & 3 & 4 & 5\end{array}$

l express opinions explicitly on government and politics via social media. $\begin{array}{llllllll}1 & 2 & 3 & 4 & 5\end{array}$

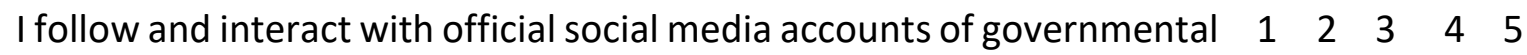
or political institutions.

I organize non-governmental campaigns or activities via social media. $\quad \begin{array}{llllll}1 & 2 & 3 & 4 & 5\end{array}$

\section{Internal political efficacy}

I can influence the enactment of new laws and political decisions. $\quad \begin{array}{lllllll}1 & 2 & 3 & 4 & 5\end{array}$

I can facilitate the election of a political leader whose views I share. $\quad \begin{array}{lllllll}1 & 2 & 3 & 4 & 5\end{array}$

I can demand those existing laws and political decisions be observed. $\quad \begin{array}{lllllll}1 & 2 & 3 & 4 & 5\end{array}$

Together citizens of my country can influence the enactment of new $1 \begin{array}{llllll}1 & 2 & 3 & 4 & 5\end{array}$ laws and political decisions.

Together citizens of my country can facilitate the election of a political $\quad \begin{array}{llllll}1 & 2 & 3 & 4 & 5\end{array}$ leader whose views they share.

Together citizens of my country can demand those existing laws and $\begin{array}{llllll}1 & 2 & 3 & 4 & 5\end{array}$ political decisions be observed.

\section{External political efficacy}

$\begin{array}{llllll}\text { The people in charge of government are willing to provide information } & 1 & 2 & 3 & 4 & 5\end{array}$ on how political decisions are made.

$\begin{array}{lllllll}\text { The people in charge of government are interested in ensuring equal } & 1 & 2 & 3 & 4 & 5\end{array}$ rights for all political parties and groups.

The people in charge of government are interested in carrying out the $\quad \begin{array}{lllllll}1 & 2 & 3 & 4 & 5\end{array}$ lawful demands of the citizens. 